\title{
Turkish ELT Professionals' Conference Attendance Motives: Why Do They Attend and What Do They Take Back Home?
}

\author{
Oya Büyükyavuz \\ Correspondence: Oya Büyükyavuz, Süleyman Demirel University, School of Education, English Language Teaching \\ Department, Doğu Campus, Isparta, Turkey.
}

\author{
Received: February 14, 2016 Accepted: February 18, 2016 Online Published: June 30, 2016 \\ doi:10.11114/jets.v4i9.1704 \\ URL: http://dx.doi.org/10.11114/jets.v4i9.1704
}

\begin{abstract}
Around the world many professionals attend conferences. The professionals working in the field of English language teaching (ELT) are not exceptions. Along with two major international conferences organized for ELT professionals, TESOL and IATEFL, there are a great number of other conferences organized by affiliated professional associations in many countries around the world. Given the time and money invested in conferences by attendees and organizers, research into this professional endeavor is almost absent in literature in this field. The present study endeavors to discover the conference attendance motives of Turkish ELT professionals, why they attend, what they are engaged in doing during conferences and what they take back home. The data for the study were collected through a questionnaire designed in four parts. A total of 83 Turkish ELT professionals who attended the 16th International INGED Conference participated in the study. The findings of the study revealed that Turkish ELT professionals attend conferences essentially to obtain new information. However, keynote speakers seem to be another major motive behind their final decision to attend a conference. Although the majority of participants stated that they spend most of their time at sessions the number of sessions that they generally attend was found to be only between 4-6. As for post-conference results, the participants were found to feel more confident, more motivated to attend conferences, and were inclined to integrate the information they obtained into their classroom practices. The study also revealed that the participants have budget-related concerns and this constitutes a major challenge with regard to conference attendance.
\end{abstract}

Keywords: professional development, ELT professionals, conference attendance, motives, Turkish ELT professionals

\section{Introduction}

In today's globalized world where knowledge is transmitted through computers at the speed of light, teachers are expected to be armed with a myriad of professional competencies to secure quality teaching and to survive. In order for teachers to keep up-to-date with the changing educational paradigms, fast-advancing technological applications in education, ever-changing students profiles and needs, they themselves must also continue to learn. Completing a pre-service teacher training program is just a start and in no way quarantees a teacher possesses competencies which will suffice throughout his/her career. Simply put, maintaining quality in education goes with those teachers who are engaged in continuous professional development (CPD henceforth) activities (Rhoton and Stile, 2002), and effective teachers are those who are always in the process of professional growth (Çelik et al. 2013). In the same vein, as stated by Allen (cited in Brown 1994) good language teachers are those who have a persistent urge to upgrade oneself, have professional citizenship, and are ready to go to the extra mile (p. 429).

The need for continuous teacher education beyond formal training has been voiced by scholars in literature. According to Lange (1990), teacher development is "a process of continual intellectual, experiential, and attitudinal growth of teachers" (p.250). Similarly, Diaz-Maggioli (2004) defines professional development as 'a career-long process in which educators fine-tune their teaching to meet student needs' (p.5). Defining CPD as 'any type of learning activity designed to enhance teachers' skills, knowledge and competencies' Bolitho (2013) provides three basic ingredients which make up the core of professional development. According to Bolitho, CPD is "knowing where we are, knowing where we want to go and knowing how to get there'.

As can be inferred from the given definitions, CPD does not refer to a state, but a process which is ongoing throughout one's career. In the literature, the distinction between 'training' and 'development' is emphasized. According to Lange (1990), training suggests a misleading 'completeness' in itself. Training refers to a certain period of learning endeavor 
which is presented or managed by others while development can be realized only by somebody for himself or herself (Wallace 1991; Banfi 2000). Another distinction drawn between training and development is that training covers short-term, that is, it starts and ends somewhere in one's life and usually serves immediate goals whereas development is longer-term oriented. While the content of a particular professional training program is decided by experts in the field development is usually initiated by somebody for himself or herself. In other words, nobody can make us develop and the decision to develop ourselves professionally requires to some extent 'self-awareness', assessment and examination of our teaching practices (Bailey et al 2001; Richards and Farrell 2005; Murray 2010). Likewise, as argued by Bolitho (2013), professional development is not standing still, but always questioning, rethinking and remaining a learner.

The current era is characterized by changing educational paradigms, fast-advancing technological applications in education, changing student profiles and accordingly changing needs, heightened societal expectations, and influx of immense information. Surrounded by all these changes in their teaching contexts teachers cannot stand still if they are to efficiently fulfill the requirements of their profession. As argued by Richards and Farrell (2005), in many schools today, "language teachers are expected to keep up to date with developments in the field, to regularly review and evaluate their teaching skills, and to take on new teaching assignments according to the changing needs of the institution" (p.ix).

According to Richards and Farrell (2005), the rationale for CPD lies in the fact that it is almost impossible to teach teacher trainees everything in pre-service education. Teaching, as a profession, they argue, is never complete and thus open to developments. Similarly, Brown (2007) describes the field of ELT as no simple, unidimentional reality ...it is 'slippery' in every way (p. 4). Thus, the prevailing concensus among researchers is that formal training that teachers receive throughout their pre-service education is limited (Lee 2002), and the initial qualification cannot quarantee 'future effectiveness as a teacher '(Barduhn and Johnson 2009). Therefore, teacher trainees should be acquainted with the concept of CPD as early as possible in their educational process, preferably when they are enrolled in formal teacher preparation programs. To this end, teacher education programs should help teacher trainees believe that participating in CPD activities is not an arbitrary conduct, but a must. In doing so, as argued by Lange (1990), teacher trainees will be able to disregard the misconception of 'completeness' that they are likely to feel after completing formal training programs.

Research into teacher development suggests that professional development has potential benefits for both teachers and the other related parties such as learners and the institutions where teachers work (Gebhard 2006; Diaz-Maggioli 2004; Richards and Farrell 2005; Murray 2010; Davidson 2013). It is assumed that teachers who participate in professional development activities are likely to move from the stage of self-survival to the stage of making informed decisions. In other words, teachers who have insatiable thirst for development will make better teachers by translating every bit of new knowledge they are likely to accumulate throughout their professional development endeavors into enlightened practices (Chisman and Crandall 2007).

Davidson (2013) has highlighted a number of the benefits of CPD for both teachers and schools. On the part of teachers, major benefits include increased 'job satisfaction, broader knowledge, skills base and ability to analyze, ability to take control of development and career planning, and development of transferable skills" (p.1). The schools which are staffed with development-oriented teachers, she argues, will definitely respond well to student needs thereby producing more desirable outcomes.

Bailey et al (2001), on the other hand, state a number of reasons why language teachers might want to participate in $\mathrm{CPD}$ activities. The first obvious reason for $\mathrm{CPD}$ involvement is to acquire new knowledge and skills. Another reason they propose is change. As mentioned earlier, the current age of information is characterized by observable changes in education-related parameters such as student needs and profiles, societal expectations, and instructonal technologies utilized in teaching contexts. Teachers can either embrace innovations emerging in their domains and try to adapt to their requirements by seizing CPD opportunities or simply ignore and resist to developing by repeating the things they have always done throughout their teaching career. Yet another reason for participation in CPD, they specify, is related to tangible rewards such as promotion, rise in salary, and prestige.

CPD activities can take many forms; some of them can be realized individually, that is, they might be comprised of solitary endeavors, while some types can be enacted in collaboration with others. Reading professional books or journal articles about the basics of the ELT field is regarded as the most fundamental CPD activity (Gebhard 2006; Bolitho 2013). Although it is a solo activity by nature, its benefits might be extended if the readers regularly get together to share and discuss what they have read in groups of other teachers.

Keeping a teaching journal is another CPD activity which can be done individually. Teaching journal is simply defined as an ongoing written account of everything about teaching. They might be in different forms varying from a simple notebook to electronic modes and might cover problems, insights, and spontaneous remedies to an emerging problem. 
Keeping a teaching journal might be both a solo and collaborative activity, if the journal entries are shared with other teachers. Crucial to keeping a teaching journal are some general procedures which need to be followed such as; deciding in advance who will be the audience and the focus of the entries, adopting a routine to make entries, and reviewing the entries regularly (Richards and Lochart 1994; Ho and Richards 1993).

Self-monitoring or self-observation is a type of CPD activity which can be undertaken in various forms. In its simplest way, it is the recorded document of someone's lesson. Recording of a lesson can be done by video-recording, audio-recording, or documenting what happened in lessons in forms of reports or narratives. The recorded segment of the lesson through video, audio or in a written format as narratives can be used by the teacher later for reflection and reviewing what occured in the actual lesson. Videotaped lesson can be used to analyze the amount of teacher talk, the use of teaching space, body language adopted to deliver lesson.

Another type of CPD is peer class observation in which a trusted observer is invited to a language classroom to watch the whole lesson or part of lesson. The goal of this CPD activity is to gain an understanding of what is going on in a particular lesson. Although observation is usually associated with evaluation, peer observation as an activity of CPD is of nonevaluative nature. That is, the observer in no way has a purpose to evaluate the observee. In order for peer observation to proceed successfully it is recommended that the pair have a pre-observation session in which the focus of observation is specified and the types of procedures to collect information are negotiated. While peer observation an observer can collect information via narratives, field notes or simply by using checklists. At the end of the observation, the observer and the observe are expected to come together in an arranged post-observation session to reflect and discuss what has been recorded.

Conducting action research is another type of CPD activity which can be realized both individually or in collaboration with others. Conducted by classroom teachers, action research includes systematic data collection on day to day practices undertaken in classrooms. The findings of action research can be used by teachers to plan their future lessons. The teachers who are involved in action research will transfer from the stage of 'consumers' of knowledge produced by researchers to the stage of 'producers' of knowledge. Utilizing this knowledge in their teachhing practices will empower them, as argued by scholars in the related literature (Richards and Farrell 2005; Wallace 1998; Wallace 1991). Furthermore, it is worth saying that the teachers who are involved in action research endeavors will be able to make informed decisions regarding their everyday teaching practices. One of the strengths of action research in relation to professional development is that it helps teachers collaborate with others by breaking the feeling of isolation, a big challenge teachers face throughout their professional teaching careers (Wallace 1998).

Yet another type of CPD activity is attending professional conferences. Conferences are generally regarded as venues where professionals get together to exchange ideas about innovative approaches, perspectives, and new techniques. They might establish professional networks, or gain professional visibility. On a more personal level, though, conference attendance has potential to provide attendees with opportunities to upgrade their existing knowledge base and broadens horizon thereby increasing self-assurance. Professionals who attend a conference become members of a community which shares mutual desires and passions (Malupa-Kim cited in Borg 2014).

Unlike seminars which adopt the mentality of 'one-size-fits all', professional conferences, as argued by Diaz-Maggioli (2004), are planned events covering a wide range of topics which might address to the needs and expectations of a majority of participants. According to Murray (2010), attending conferences is beneficial in many respects. Conference attendance helps the ELT professionals gain confidence and demonstrate their expertise by interacting and developing personal contacts in the English teaching community. What is more, the teachers who attend conferences are likely to be motivated to try and test new techniques based on the baseline information they would accumulate during conferences. More importantly, according to Murray, teachers can feel empowered and take on more leadership in their teaching contexts by sharing and teaching what they have learned with their colleagues upon their return from conferences. Similarly, Ur (2012) asserts that through attending conferences teachers can update their knowledge on the latest research and new issues in the field, learn new techniques and methods utilized in the field and familiarize themselves with the most recently released teaching materials and establish professional networks in local and international areana. On the other hand, Crandall (cited in Borg 2014) ) sums up the potential benefits of conferences by saying 'there is perhaps no single experience with more potential for educating and refreshing a professional than an international English language teaching conference' (p.536).

Although professional conferences might have long-lasting constructive effect on someone's professional career the literature lacks emprical studies regarding conference attendance. In a recent study conducted by Borg (2014), a total of 66 ELT professionals' opinions about the impact of conferences on their professional development were investigated. The data collected through questionnaires and interviews revealed that the majority of the participating ELT professionals developed positive feelings after attending conferences. 
Established in 1995, English Language Teaching Association (INGED) serves the ELT professionals in Turkey as the only official ELT organization. Since its establishment, the association has organized 16 international conferences in Turkey. The average number of attendees at these conferences is around 150 (personal conversation with the secretary of the association). The goal of the association, as stated on the official website, is to 'bring together English language professionals from all levels of education in Turkey'. More specifically, the association aims to provide a scholarly platform to exchange professional experiences, opinions and findings. English Language Education Association (INGED) in Turkey serves its members as TESOL affiliate and IATEFL associate.

As of 2014, the association has 2500 members working as ELT professionals either in public, private schools or at universities. Given the fact that the total number of English language teachers is 61.419 (Ministry of National Education Report, 2014), it can be said that there are many ELT professionals in Turkey who are unaware of the existence of such a professional association available to them and naturally the conferences the organization hosts. Apart from those sponsored by INGED, there have been a growing number of international conferences organized by private high schools and universities in Turkey in recent years. A total of 20 international ELT conferences were organized by universities or private high schools between the dates 27 January 2014 and 19 September 2014 in Turkey (Gurr 2014).

Although attending conferences is regarded as a promising professional development endeavor that attracts thousands of ELT professionals around the world, to our surprise, literature in the field lacks studies addressing this activity. With this in mind, the present study was conducted to provide insights into conference attendance motivation of the Turkish ELT professionals. This study questions why they attend conferences, what kinds of activities they are engaged in during conferences, how they feel after attending conferences and what exactly they take back home.

\section{Method}

\subsection{Research Questions}

The primary goal of the current study was to identify the underlying motives before, during and after conference attendance of the Turkish professionals working in the field of English language teaching. More specifically, the present research was guided by the following research questions:

1. What are the motives of the Turkish ELT professionals before professional conferences in terms of the major reason to attend, the most important criterion when planning to attend, and the major source of information regarding professional conferences?

2. What are the motives of the Turkish ELT professionals during the conference in terms of the number of sessions they attend, the major reason to attend a session, and the activities that occupy most of their time during conferences?

3. What are the motives of the Turkish ELT professionals after attending a professional conference in terms of maintaining a network with the professionals they meet, their feelings after attending conferences, and the activities they are involved in upon return?

Along with these questions which were designed to elicit the motives in terms of before, during and after conference attendance, the Turkish ELT professionals were also asked to state the institution's attitude and the most important challenge they encounter with regard to attending conferences.

\subsection{Participants}

The sample of the study was comprised of the attendees of the 16th INGED International Conference held in İzmir, Turkey in 2013. The reason this conference was selected is that INGED is the only official organization for ELT professionals in Turkey. A total of 83 attendees participated in the study. Of them, 58 (69.9\%) were female and 25 $(30.1 \%)$ were males. The ages of the participants ranged between 24 to 52. As for academic position, 16.9\% ( $\mathrm{N}=14)$ of the participants were practicing English language teachers, while $41 \%$ of them were instructors working at various universities across the country and $42 \%$ of them were faculty in the ELT departments in the Schools of Education as assistant professors, associate professors or full professors. Of the participants $44.6 \%(\mathrm{~N}=37)$ stated they attended $1-3$ professional conferences, 32.5\% ( $\mathrm{N}=27)$ 4-6 conferences, $16.9 \%(\mathrm{~N}=14) 7-10$ conferences, and 6\% $(\mathrm{N}=5)$ attended more than 10 professional conferences in the last two years.

\subsection{The Data Collection Instrument}

Survey method was utilized to collect the data for the study. The questionnaire was developed by the researcher and included four parts. The first part of the questionnaire included four questions eliciting demographic information about attendees such as gender, age, current position at work, and the number of the professional conferences attended in the last two year. The second part was designed to collect information about the attendees' motives for attending professional conferences. The last two parts of the questionnaire included questions to elicit information about the 
attendees' motives during and after conferences. The questionnaire was piloted with a group of teaching staff who work in the School of Education at Süleyman Demirel University and regularly attend conferences. Based on the pilot study various modifications were made in terms of clarity of some items included in the questionnaire. Along with the questionnaires, the researcher conducted informal interviews with fifteen attendees between sessions during breaks.

\subsection{Data Collection and Analysis}

To conduct the research permission was obtained from the president of INGED before the conference. The questionnaire was administered randomly to the attendees during the 16th INGED international conference which was hosted by the School of Foreign Languages at Dokuz Eylül University in İzmir in 2013. Of a total of 150 ELT professionals who attended the conference (personal communication with the secretary of INGED) 83 returned the questionnaires. In order to reach to a maximum number of participants, the administration of the questionnaires was scheduled on the first and the second day of the conference.

The data collected through the questionnaires were analyzed by using SPSS 17. Descriptive statistics was used to analyze the demographic information included in the first part of the questionnaire. In order to analyze the research questions, frequencies and percentages were computed. The results were presented either in tables or in paragraphs for reasons of space.

\section{Findings}

\section{Research Question 1: What are the motives of the Turkish ELT professionals before professional conferences?}

\section{$1 \mathrm{a}$. Motives in terms of the most important reason to attend professional conferences}

In this part of the questionnaire, three questions were asked which are related to motives before attending professional conferences. As can be seen from the Table $1,70 \%$ of the attendees $(\mathrm{N}=58)$ reported that they attend conferences to obtain new information about their profession. The second most important reason for conference attendance was found to be related to professional networking, that is, $17 \%$ of the attendees stated that they attend professional conferences to meet other professionals working in the field of English language teaching.

Table 1. The most important reason for The Turkish ELT professionals to attend professional conferences

\begin{tabular}{lll}
\hline reasons to attend conferences & Frequency & Percent \\
\hline to obtain new information about my profession & 58 & 69.9 \\
to meet professionals working in the same field with me & 14 & 16.9 \\
to meet my friends working in the same field at different & 4 & 4.8 \\
universities across the country & 1 & 1.2 \\
to meet some of the criteria for appointment & 4 & 4.8 \\
to have a break from work life & 2 & 2.4 \\
to acquire techniques and knowledge to apply to my teaching & 83 & 100.0 \\
Total & & \\
\hline
\end{tabular}

Ur (2012) argues that at conferences much interesting learning takes place between sessions as during them. The researcher conducted informal interviews between sessions during breaks with fifteen professionals who were working as assistant professors at various universities. When the researcher asked the major reason to attend conferences 6 out of 15 assistant professors pronounced concerns of reappointment. In Turkey, unlike associate professors, assistant professors have to submit a file documenting professional works such as published articles or the conference presentations in order to guarantee reappointment every two or three years.

\section{$1 \mathrm{~b}$. Motives in terms of the most important criteria when planning to attend a conference}

For $45.8 \%$ of the Turkish ELT professionals $(\mathrm{N}=38)$, the most important criterion when planning to attend conferences was the keynote speaker. Location of the conference was also found to be a major motive for $36.1 \%$ of the participants. During the informal interviews some of the attendees stated that if the conference is held in a location they would be interested in visiting they want to attend. The theme of the conference was important to only 11 participants. The topics of the papers, cost of registration fee and availability of convenient accommodation were revealed as the least important criteria by the participants.

\section{$1 \mathrm{c}$. Motives in terms of the major source of information regarding professional conferences}

The last question in this section regarding the pre-conference motives asked the Turkish ELT professionals the source of the information about an upcoming conference. The majority of the attendees $(33.7 \% \mathrm{~N}=28)$ stated that they hear about an upcoming conference from the professional organization they are members of. The second major source of information $(31.3 \%)$ was found to be internet searches $(\mathrm{N}=26)$. The other sources were stated by the participants as their friends $(19.3 \%)$ and from the institution they work for $(15.7 \%)$ respectively. 
Research Question 2. What are the motives of the Turkish ELT professionals during a professional conference?

\section{2 a. Motives in terms of the number of sessions the Turkish EFL professionals participate}

Of the participants $47 \%$ stated that $(\mathrm{N}=39)$ they generally attend $4-6$ sessions, $7.2 \%(\mathrm{~N}=6) 1-3$ sessions, 32.5\% $(\mathrm{N}=27)$ $7-10$ sessions, and $13.3 \%(\mathrm{~N}=11)$ attend more tha 10 sessions. Given that a typical international conference lasts approximately two-three full days with approximately more than 50 concurrent sessions the number of the sessions the participants generally attend is relatively low. For instance, the INGED conference during which the data for this research were collected included three plenary sessions and 21 concurrent sessions on the first day, and 44 concurrent sessions with two plenary sessions on the second day. The last day of the conference was devoted to two plenary speeches and roundtable discussions.

\section{$2 \mathbf{b}$. Motives in terms of the criteria to choose a session to attend during a conference}

In this part of the questionnaire, the participants were asked to identify the criteria to select a session. As can be seen from the Table 2, the majority of the Turkish EFL professionals $(38.5 \%, \mathrm{~N}=32)$ select a session based on its relevance to the topic of their interest while $26.5 \%$ of them choose a session in accordance with its relevance to the problems they encounter in their teaching contexts. Of the participants $13 \%$ select a session based on the presenter and $12 \%$ decide to attend a session to learn about a new topic.

Table 2. Criteria to choose a session during a conference

\begin{tabular}{lll}
\hline I select a session based on & Frequency & Percent \\
\hline its relevance to the topic I am interested in & 32 & 38.5 \\
the presenter & 11 & 13 \\
the time slot of the session & 1 & 1.2 \\
my personal relationship, if any, with the presenter & 4 & 4.8 \\
its being a contemporary topic & 3 & 3.6 \\
its relevance to the problems I encounter in my teaching & 22 & 26.5 \\
context & 10 & 12 \\
my enthusiasm to learn about a new topic & 83 & 100.0 \\
Total & & \\
\hline
\end{tabular}

$2 \mathrm{c}$. Motives in terms of activities they devote the most of their time during conferences

Of 83 participants $59(71.1 \%)$ stated that they spend most of their time at the sessions while $21.7 \%$ stated they socialize with their friends, while still some others spend most of their time browsing the books displayed by the vendors (2.4\%) and have scholarly discussions (4.8\%). Compared to the number of sessions generally attended by participants which is 4-6 sessions ( $47 \%$ of the participants $\mathrm{N}=39$ ), this result seems to be open to further discussion.

Research Question 3. What are the motives of the Turkish ELT professionals after attending a professional conference?

3 a. Motives in terms of maintaining network with the new colleagues the Turkish ELT professionals meet at the conferences

As mentioned earlier, conference attendance provides attendees professional networking opportunities which have been emphasized as major benefits of conferences (Murray 2010; Richards and Farrell 2011; Ur 2012). In the current study, $72.3 \%$ of the participants $(\mathrm{N}=60)$ stated that they sometimes stay in touch with the new colleagues they meet at the conferences whereas only $20.5 \%$ of them $(\mathrm{N}=17)$ always maintain communication. Of the participants, $7.2 \%$ stated that they never keep in touch with new colleagues they are acquainted with at the conferences.

\section{$3 \mathrm{~b}$. The Turkish ELT professionals' feelings after attending conferences}

As can be seen the Table 4 below, the majority of the participants (55.4\%) feel 'confident' when they return home after obtaining new knowledge while some of them (12\%) feel 'insecure' that they are surrounded by immense amount of new knowledge. The feeling of confidence which has been stated by the Turkish EFL professionals is in agreement with the finding of the study conducted by Borg (2014) study. In his study, $81.8 \%$ of the language professionals stated that they feel confident after attending conferences. Similarly, in both studies the participants expressed increased motivation to go to conferences. 
Table 3. The feelings that Turkish ELT professionals generally have after attending a conference

\begin{tabular}{lll}
\hline post-conference feelings & Frequency & Percent \\
\hline I feel insecure that I am surrounded by immense amount of & 10 & 12.0 \\
new knowledge & 46 & 55.4 \\
I feel confident that I have obtained new knowledge & 16 & 19.3 \\
I feel motivated to attend more conferences & 8 & 9.6 \\
I want to apply the things that I have learned at the conference & 8 & 3.6 \\
in my teaching context & 3 & 100.0 \\
I feel like getting back home immediately. & 83 \\
Total
\end{tabular}

\section{$3 \mathrm{c}$. The activities that Turkish EFL professionals are involved in upon return home}

In this question, the participants were asked to state post-conference motives. That is, what the conference attendees are engaged in doing when they return home. Table 4 reveals that the majority of the participants (28.9\%) have an intention to transfer the knowledge they obtained during conference to their classroom contexts. Of the participants $22.9 \%$ stated that they put aside all the printed materials for reviewing later while $21.7 \%$ share the knowledge they obtained with their colleagues upon return.

Table 4. Post-conference motives of the Turkish ELT professionals

\begin{tabular}{lll}
\hline post-conference activities & Frequency & Percent \\
\hline $\begin{array}{l}\text { I organize all the notes/hand outs and documents I acquired } \\
\text { I share the knowledge I have obtained during the conference with }\end{array}$ & 12 & 14.5 \\
my colleagues who couldn't attend the conference & 18 & 21.7 \\
I put a side all the notes, documents,and sample materials I have & 19 & 22.9 \\
$\begin{array}{l}\text { collected during the conference for reviewing later } \\
\text { I identify topics for future research projects based on the knowledge }\end{array}$ & 10 & 12.0 \\
$\begin{array}{l}\text { I have obtained during the conference } \\
\text { Based on their relevance and appropriatness I try to integrate the } \\
\text { knowledge I have obtained into my classroom practices }\end{array}$ & 24 & 28.9 \\
Total & 83 & 100.0 \\
\hline
\end{tabular}

The participating ELT professionals were asked about the attitude of ther institution toward conference attending. Almost half of the participants $(47 \% \mathrm{~N}=39)$ stated that their institution supports their conference attandance while others stated that $(33.7 \% \mathrm{~N}=28)$ their institution is positive about their conference attendance on condition that they do not have any other assignments, duties and responsibilities. The particpants were also asked about the most important challenge in terms of conference attendance out of 83 participants $48(57.8 \%)$ stated financial problems as the most important challenge. The other challenges were found to be related to work or familial issues, $25.3 \%$ and $16.9 \%$, respectively.

\section{Discussion}

Around the world thousands of professionals invest time, energy and money in attending conferences. Along with two big conferences that is TESOL in the United States and IATEFL in the United Kingdom, a great number of conferences are organized in many countries around the world for the professionals working in the field of ELT. Although these conferences attract many professionals emprical research into any aspects of these high-profile events is largely absent in literaturein the field. The present study was conducted to contribute to the nonexistent pool of data from the Turkish context. A total of 83 ELT professionals' motives before, during and after an international conference organized by INGED, the official organization for ELT professionals in Turkey, were investigated via a four-part questionnaire. The study was of descriptive design and aimed at providing baseline data for possible further studies.

The findings of the study revealed that the Turkish ELT professionals (69.9\%) attend conferences primarily to obtain new information about their profession. However, the informal interviews conducted with fifteen assistant professors between sessions suggested the participants were concerned about reappointment. Although this finding was not confirmed with the data collected through the questionnaires it has potential for further investigation at least in the Turkish context where attending or presenting papers at conferences meets some of the basic criteria required for reappointment of assistant professors. For $45.8 \%$ of the participants, the keynote speaker is the major motive when planning to attend a conference and the second motive is the location of the conference (36.1\%). Informal interviews which were conducted during breaks with a total of 15 attendees somehow back up this finding that some of them simply decide to attend a conference based on its location. Almost half of the participants $(47 \% \mathrm{~N}=39)$ stated that they attend 4-6 sessions during a conference. The INGED conference at which the data for the present study were collected included 65 concurrent sessions excluding plenary speeches.

Of the 83 participants $59,(71.1 \%)$ stated that they spend most of their time at sessions during a conference. Comparing this to the total number of sessions the participants generally attend, which is $4-6$, this finding seems to be open to 
discussion. The majority of the respondents ( $38.5 \% \mathrm{~N}=32$ ) stated that the primary motive for their decision to attend a session was inspired by the relevance of the topic to their interest while for some others (26.5\%) the topic's relevance to the problems in teaching context was an important criterion for selecting a session. Academic visibility and establishing networks among local and international colleagues are regarded to be major benefits of conference attendance. The majority of the participants (72.3\%) in the present study stated that they sometimes stay in touch with new colleagues they meet at conferences while $20.5 \%$ of them always maintain network.

As for the post-conference feelings and the actvities the participants are involved, more than half of the participants (55.4\%) feel 'confident' as they return home relatively more knowledgeable after conferences. This finding is in harmony with the findings of the study conducted by Borg (2014) with the participation of 66 ELT professionals working in seven Gulf countries. The majority of the respondents stated that they feel motivated to go to conferences (92\%) and feel more confident $(81.8 \%)$. Of the respondents $19.3 \%$ stated that they are more motivated to attend conferences whereas $12 \%$ of them feel 'insecure' after getting immersed in wealth of new information. Of 83 respondents $28.9 \%$ stated that they make use of the professional information they accumulated during conferences in their classrooms. Of the Turkish ELT professionals 21.7\% stated that they share what they have learned at conferences with their colleagues and $12 \%$ of them identify research topics based on new knowledge they obtain during conferences. The respondents stated that the institutions they work for are positive about their conference attendance. However, their economic situation was found to be a major challenge for half of respondents with regard to conference attendance.

\section{Conclusion}

As mentioned earlier, there have been almost no emprical studies conducted to investigate the aspects of conference attendance, even though they attract and occupy thousands of professionals. This study was conducted to provide descriptive baseline data regarding the conference attendance motives of the Turkish ELT professionals. One of the findings of the research was that the Turkish ELT professionals have financial concerns with respect to conference attendance. This problem can be overcome by organizing seminars by the conference attendees for those who cannot afford to attend conferences. This kind of interaction will be also rewarding in terms of building a learning community and collegiality among colleagues who work in the same institutions.

The study can be replicated in different contexts with different and larger sample. The current research was of descriptive design, other studies can be modelled to investigate the correlation between conference attendance motives and some variables such as gender and academic position. Studies can be conducted on the ways as to how attendees can get maximum professional benefits out of conferences. Other studies could investigate long-term benefits of conference attendance to see whether attendees continue to translate the obtained information into actual classroom practices on a long term basis.

\section{References}

Bailey, K. M., Curtis, A., \& Nunan, D. (2001). Pursuing Professional Development the Self as Source Canada: Heinle \& Heinle.

Banfi, C. (2000). Some thoughts on the professional development of language teachers, in ELT News and Views Supplement 4.1. Teacher Development, March, 13-16.

Barduhn, S., \& Johnson, J. (2009). Certification and Professional qualifications. In: JC Richards and A. Burns (Ed.). The Cambridge Guide to Second Language Teacher Education. New York: Cambridge University Press, 59-65.

Bolitho, R. (2013). The dimensions of continuing professional development. www.youtube.com/watch?v=nCA5ZKNQYnk

Borg, S. ( 2014). The benefits of attending ELT conferences. ELT Journal, 8(4), 1-12.

Brown, H. D. (2007). Principles of Language Learning and Teaching. New York: Pearson Longman.

Çelik, S., Arikan, A., \& Caner, M. (2013). In the Eyes of Turkish EFL Learners: What Makes an Effective Foreign Language Teacher? Porta Linguarum, 20(2), 287-297.

Chisman, F. P., \& Crandall, J. A. (2007). Passing the torch: Strategies for innovation in community college ESL. New York, NY: Center for Advancement of Adult Literacy. http://www.caalusa.org/eslpassingtorch226.pdf

Davidson, G. (2013). Continuing professional development. http://www.teachingenglish.org.uk/search/site/gillian\%20davidson

Diaz-Maggioli, G. H. (2004). Teacher-centered Professional Development ASCD Publications Alexandria USA.

Gebhard, J. G. (2006). Teaching English as a Foreign or Second Language: Teacher Self-developmentand Methodology Guide. Michigan: University of Michigan Press. http://dx.doi.org/10.3998/mpub.147778 
Grandall, J. (2001). Keeping up to date as an ESL or EFL professional. In: M. Celce-Murcia (Ed.): Teaching English as a Second or Foreign Language. New York: Boston, 183-194.

Gurr, T. (2014). ELT conference list. https://allthingslearning.wordpress.com/tag/tony-gurrs-blog

Ho, B., \& Richards, J. C. (1993). Reflective thinking through teacher journal writing: Myths and realities. Prospect: A Journal of Australian TESOL, 8, 7-24.

Lange, D. (1990). A blueprint for a teacher education program. In: JC Richards and D. Nunan (Ed.). Second Language Teacher Education. Cambridge: Cambridge University Press, 245-268.

Lee, M. S. (2002). Teaching English as an International Language. Oxford: Oxford University Press.

Malupa-Kim, M. (2011). Professional development: why attending conferences counts'. TESOL. Inc.

Murray, A. (2010). Empowering teachers through Professional development, English Teaching Forum, 1(48), 2-11.

Rhoton, J., \& Stiles, K. E. (2002). Exploring the professional development design process: Bringing an abstract framework into practice. Science Educator, 11(1), 1-8. http://dx.doi.org/10.1023/A:1013048828150

Richards, J. C., \& Farrell, T. S. C. (2005). Professional Development for Language Teachers. New York: Cambridge University Press. http://dx.doi.org/10.1017/CBO9780511667237

Richards, J. C., \& Lockhardt, C. (1994). Reflective Teaching in Second Language Classroom. Cambridge: Cambridge University Press. http://dx.doi.org/10.1017/CBO9780511667169

Richards, J. C., \& Farrell, T. S. C. (2011). Practice Teaching A Reflective Approach. New York: Cambridge University Press. http://dx.doi.org/10.1017/CBO9781139151535

Ur, P. (2012). A Course in English Language Teaching. Cambridge University Press: UK.

Wallace, M. J. (1991). Training Foreign Language Teachers A reflective Approach. Cambridge: UK Cambridge University Press.

Wallace, M. J. (1998). Action Research for Language Teachers. Cambridge: UK Cambridge University Press.

\section{$(\mathrm{cc}) \mathrm{BY}$}

This work is licensed under a Creative Commons Attribution 3.0 License. 